\title{
The Reading Strategies Used by EFL Students: A Case of Iranian Advanced English Language Learners
}

\author{
Mehdi Hatami \\ Department of English Language, Islamic Azad University, Ahar, Iran \\ Hanieh Davatgari Asl \\ Department of English Language, Islamic Azad University, Ahar, Iran
}

\begin{abstract}
The present study aims at identifying reading strategy choice of Iranian advanced English language learners. To this end, the main instrument was Metacognitive Awareness of Reading Strategies Inventory (MARSI) Questionnaire. It was given to 110 Iranian advanced English language learners, male and female, at 19 English language institutes in northern part of Iran. Students had to choose among the five different options for each strategy type in order to specify whether they "I never or almost never do this.", "I do this only occasionally.", "I sometimes do this.", "I usually do this." or "I always or almost always do this.". Among the three different groups of strategies namely support reading strategies, problem solving strategies and global reading strategies the findings indicated that student at this level of English proficiency have a tendency toward using support reading strategies than other types.
\end{abstract}

Index Terms—reading, strategy, metacognitive awareness, EFL learners, problem solving

\section{INTRODUCTION}

The core principle of the grammar translation method was teaching Reading and ever since this skill has gained much attention. In addition, in 1929 Coleman Report changed the game with shifting the intention of reading as reading for translation towards reading without translation. The logic that lies behind was developing an idea of independent silent reading and in order to expedite reading speed of individuals. Reading skill based on Krashen (1985) was mostly considered as comprehensible input which is the mere reason to paving the way for obtaining competence in productive skills, namely speaking and writing. With this regard Krashen (1985) also emphasized voluntary reading as an approach that can cover a range of communicative language competence to academic language competence.

A psycholinguistic view of reading was generated by Goodman et al. (1995) where reading was mostly defined as an interactive process between the reader and the writer. The significance of Reading can be justified by language learners' need to read academic texts. Learners try to recall background knowledge, have an aptitude of text schema, terminology and grammatical awareness, and their personal objectives as various sub skills to grasp the meaning of the written material which is why reading is defined as an interactive process. (Grabe, 1991)

Because the reading skill is more or less a key skill in academic context, this study investigates to deliver different kinds of reading strategies advanced English language learners tend to use in Iranian EFL context. With regard to implementations of the findings of the current study, syllabus designers, material developers and lesson planners can benefit from them. Throughout the literature there has been no study resembling the current one which is conducted in an Iranian setting on Iranian advanced English language learners.

Research questions

The questions that this study intends to address are as follow:

1. What are the most and least reading strategies used by the Iranian advanced English language learners?

2. What groups of strategies do the Iranian advanced English language learners prefer?

\section{CONCEPTUAL FRAMEWORK}

\section{A. Reading, the Reading Process, Reading Strategies}

According to Ransom (1978) reading is "a conversation between the writer and the reader" (p. 14). Besides, Nuttall (1996) explains it "the process of getting out of the text as nearly as possible with the message the writer puts into it" (p. 4)

with this regard, Williams (1996) outlines that reading is "a process through which one looks at and understands a written text" (p. 2). Reading is defined as a compound process of gaining meaning from a text for several objectives in various contexts (Allan \& Bruton, 1997.)

Following definition is given by Mikulecky (2008) with regard to reader's role: 
Reading is a conscious and unconscious thinking process. The reader applies many strategies to reconstruct the meaning that the author is assumed to have intended. The reader does this by comparing information in the text to his or her background knowledge and prior experience. (p. 1)

A reader examines a text with an enormous pool of prior knowledge and experience, consisting of preconceptions about the uses of language in both spoken and written form. All of an individual's prior knowledge, experience, and values are organized in classes, or schemata. Each category, or schema, is connected to many other schemata in a complex mental network. As the reader notices particular ideas or facts in a text, he matches that information with background knowledge and is able to construct a version of the text's meaning. (Mikulecky 2008)

In addition, in the reading process, readers take advantage of their background and their linguistic knowledge about the topic to meet the objective of the reading (Peregoy \& Boyle, 2001).

reading strategies according to Garner (1987) are actions or series of actions implemented in order to draw meaning out of a text. Readers mostly use a variety of strategies to acquire, store and retrieve the information. Readers can confront some comprehension difficulties and apply these strategies to overcome their hurdles. Every individual benefits from different strategies and some of them lead to target in a faster and clearer way. (Tercanlıoğlu, 2004)

Difficulties EFL learners usually confront when reading consists of insufficient vocabulary, inefficiency lexical items, grammatical complexity, inaccessibility of language, poor reading skills, lack of background knowledge, and Learners' lack of interest.

\section{B. Types of Reading}

\section{Academic Reading}

Academic life covers different areas as such are the various examinations each student has to pass. These examinations usually require the learner to understand a given passage which follows some questions require learners to answer based on the information they obtain from the passage. (Grellet, 1996)

2. Non-academic Reading

Non-academic reading as opposed to academic reading is defined by any sort of reading an individual would like to start with no intention for passing any examinations. This kind of reading is open and readers can select from a wide range of reading materials according to their preferences, options for choice and the amount of time they can spend reading.

3. Intensive Reading

Readers extract specific information from quite short passages. According to Brown (1989) "intensive reading calls attention to grammatical forms, discourse markers and other surface structure details for the purpose of understanding literal meaning, implications, rhetorical relationships" (p .41).

4. Extensive Reading

Extensive reading is defined as an individualized approach to reading improvement. Students choose their own reading material and read at their own pace. Williams (1984) defines extensive reading as the "relatively rapid reading of long texts" (p. 82). Extensive reading is actually a private and personalized task in which the reader is willing to dwell in his private world of reading for his very own interest. Extensive reading helps the readers to improve their reading skills, serves a different atmosphere for the students and provides them with enjoyment (Nuttall 1996).

Extensive reading according to Day and Bamford (1998), in a second-language curriculum can play the role of "a separate course; as part of an existing reading course; as a non-credit addition to an existing course; and as an extracurricular activity" (p. 41,). The focus is on the quantity of reading materials and the readers' enjoyment of their reading. There is no formal assessment in extensive reading.

\section{Approaches to Reading}

Scholars in text comprehension have implemented an information-processing comparison to understanding how people think, learn, and remember what they read. When an individual reads, two aspects of this "human information processing system" unceasingly interact. When the reader focuses primarily on what he or she already knows, this is called a concept-driven or "top-down" mode. Top- Down processing is to comprehend the universal meaning of the text through cues in the text and the reader's good prior knowledge. Reader's expectations of the text play an essential role in this process. The reader brings his personal experiences which highly affect the way of interpreting a text. Top-down approach uses the meaning brought by the reader, namely, it is reader-driven. (Mikulecky 2008)

Nevertheless, the most effective model is the interactive model that is a combination of both bottom-up and top down elements. (Anderson, 1999)

\section{METHOD}

The current study aims at determining the kinds of reading strategies that the Iranian advanced English language learners use to accomplish in reading assignments and tasks. Needless to say, syllabus designers, material developers and lesson planners can benefit from the outcomes of this study.

\section{A. Participants}


The study was conducted at 19 English language institutes in Tonekabon, Chaloos and Nowshahr. The participants were 110 Iranian advanced English language learners. The mean age was 27 . The variety of gender was as follows: $80 \%$ of the participants were female while $20 \%$ of them were male teachers.

\section{B. Instruments}

Metacognitive Awareness of Reading Strategies Inventory (MARSI) Questionnaire was the main instrument used to collect data about the readers' awareness and use of reading strategies when reading academic materials.

The MARSI Questionnaire (Mokhtari and Reichard, 2002) measures three classes of reading strategies which is consisting of:

(1) Global Reading Strategies (GLOB), which can be categorized as generalized or global reading strategies that is defined to set the stage for the reading act.

(2) Problem-Solving Strategies (PROB), delineated as focused problem solving or repair strategies are mostly used with the inception of different problems in understanding textual information, and

(3) Support Reading Strategies (SUP), that are known as the support mechanisms and function as sustaining responsiveness to reading.

The internal consistency reliability coefficient of the 30 -item questionnaire ranged from 0.89 to 0.93 which was validated by Mokhtari and Reichard (2002). It is a five point Likert scale questionnaire ranging from 1 (I never or almost never use this strategy) to 5 (I always or almost always use this strategy). The flowing statistics were measured using SPSS program: frequency, means and standard deviation.

\section{FINDINGS AND RESULTS}

The following table illustrates the most and the least reading strategy used by Iranian advanced English language learners.

TABLE 1.

READING STRATEGIES REPORTED BEING USED THE MOST AND THE LEAST

\begin{tabular}{|c|c|c|c|c|}
\hline Items & & 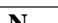 & M & \\
\hline When text becomes difficult, I pay closer attention to what I am reading. & PROB & 110 & 4.38 & 1.14 \\
\hline I take notes while reading to help me understand what I read. & SUP & 110 & 4.14 & 0.94 \\
\hline When text becomes difficult, I read aloud to help me understand what I read. & SUP & 110 & 3.88 & 0.9 \\
\hline When text becomes difficult, I reread to increase my understanding. & PROB & 110 & 3.49 & 1.05 \\
\hline I underline or circle information in the text to help me remember it. & SUP & 110 & 3.28 & 1.2 \\
\hline I ask myself questions I like to have answered in the text. & SUP & 110 & 3.17 & 1.16 \\
\hline I try to get back on track when I lose concentration. & PROB & 110 & 2.86 & 0.99 \\
\hline I skim the text first by noting characteristics like length and organization. & GLOB & 110 & 2.62 & 1.08 \\
\hline I adjust my reading speed according to what I am reading. & PROB & 110 & 2.19 & 1.1 \\
\hline I discuss what I read with others to check my understanding & SUP & 110 & 1.91 & 0.93 \\
\hline
\end{tabular}

According to the findings students pay closer attention to what they are reading when the text gets more difficult firstly and in the next move they would read the text aloud to help them understand it and reread to increase their understanding. As far as the support reading strategies go, students would rather take notes while reading to understand and underline or circle information in the text to help them remember. As the tabulated findings suggest students have more tendency toward the usage of support reading strategies than problem solving strategies and global reading strategies are the least used strategies based on the findings.

TABLE 2.

THREE THE MOST AND THE LEAST USED READING STRATEGIES REPORTED BY MALES AND FEMALES

\begin{tabular}{|c|c|c|c|c|c|c|c|}
\hline Items & Group & $\mathbf{N}$ (male) & $\mathbf{M}$ & SD & $\mathbf{N}$ (female) & $\mathbf{M}$ & SD \\
\hline $\begin{array}{l}\text { When text becomes difficult, I pay closer attention to } \\
\text { what I am reading. }\end{array}$ & PROB & 22 & 4.22 & 1.2 & 88 & 4.36 & 0.97 \\
\hline $\begin{array}{l}\text { I underline or circle information in the text to help me } \\
\text { remember it. }\end{array}$ & SUP & 22 & 3.98 & 1.08 & 88 & 4.11 & 1 \\
\hline $\begin{array}{l}\text { I adjust my reading speed according to what I am } \\
\text { reading. }\end{array}$ & PROB & 22 & 3.67 & 0.98 & 88 & 3.85 & 1.02 \\
\hline $\begin{array}{l}\text { I take notes while reading to help me understand what I } \\
\text { read. }\end{array}$ & SUP & 22 & 3.21 & 1.1 & 88 & 3.40 & 1.04 \\
\hline $\begin{array}{l}\text { I skim the text first by noting characteristics like length } \\
\text { and organization. }\end{array}$ & GLOB & 22 & 2.8 & 1.21 & 88 & 3 & 0.9 \\
\hline $\begin{array}{l}\text { I discuss what I read with others to check my } \\
\text { understanding }\end{array}$ & SUP & 22 & 2.04 & 0.96 & 88 & 1.8 & 0.94 \\
\hline
\end{tabular}

In terms of the two groups of male and female language learners, the findings suggest that more female learners tend to use support reading strategies than problem solving strategies and global reading strategies. In this case both groups have a high tendency to pay closer attention to what they are reading when the text gets difficult. 
TABLE 3.

ITEM STATISTICS OF GLOBAL READING STRATEGIES

\begin{tabular}{|l|l|l|l|}
\hline Items & N & M & SD \\
\hline I use typological aids like boldface and italics to identify key information. & 110 & 4.1 & 1.2 \\
\hline I have a purpose in mind when I read. & 110 & 3.67 & 1.05 \\
\hline I use context clues to help me better understand what I am reading. & 110 & 3.24 & 1.08 \\
\hline I preview the text to see what it is about before reading it. & 110 & 3.13 & 0.98 \\
\hline I skim the text first by noting characteristics like length and organization. & 110 & 3.08 & 0.91 \\
\hline I decide what to read closely and what to ignore. & 110 & 2.87 & 0.94 \\
\hline I check my understanding when I come across conflicting information. & 110 & 2.66 & 1.23 \\
\hline I use tables, figures, and pictures in text to increase my understanding. & 110 & 2.47 & 1.14 \\
\hline I check to see if my guesses about the text are right or wrong. & 110 & 2.29 & 0.93 \\
\hline I try to guess what the material is about when I read. & 110 & 2.18 & 0.91 \\
\hline I critically analyze and evaluate the information presented in the text. & 110 & 2 & 1.1 \\
\hline I think about what I know to help me understand what I read. & 110 & 1.88 & 0.97 \\
\hline Total & & 2.79 & \\
\hline
\end{tabular}

Global reading strategies that are used by Iranian advanced English language learners are tabulated in table 3. The findings show that the readers use typological aids like boldface and italics to identify key information as their mostly used global reading strategy. They have a purpose in mind to help them decipher the text when they are reading. In order to understand a text better they try to use context clues which are used more than tables, figures and pictures. Minimum number of participants think about what they know to help them understand what they read.

TABLE 4.

ITEM STATISTICS OF SUPPORT READING STRATEGIES (SUP)

\begin{tabular}{|l|l|l|l|}
\hline Items & N & M & SD \\
\hline I underline or circle information in the text to help me remember it. & 110 & 4.4 & 0.98 \\
\hline I use reference materials such as dictionaries to help me understand what I read. & 110 & 4.08 & 1.1 \\
\hline I paraphrase (restate ideas in my own words) to better understand what I read. & 110 & 3.87 & 1.2 \\
\hline I discuss what I read with others to check my understanding & 110 & 3.64 & 1.07 \\
\hline I summarize what I read to reflect on important information in the text. & 110 & 3.39 & 1.13 \\
\hline I go back and forth in the text to find relationship among ideas in it. & 110 & 2.79 & 0.94 \\
\hline I take notes while reading to help me understand what I read. & 110 & 2.64 & 1.03 \\
\hline When text becomes difficult, I read aloud to help me understand what I read. & 110 & 2.2 & 0.9 \\
\hline I ask myself questions I like to have answered in the text. & 110 & 1.98 & 0.99 \\
\hline Total & & 3.22 & \\
\hline
\end{tabular}

In terms of the use of support reading strategies which were picked most often by the participants the most SUP strategy was underlining or circling information in the text in order to help them understand the text. The other way that advanced readers take in order to understand their reading material is to use dictionary. Paraphrasing or restating the ideas in their own words stand in the next rank according to the findings illustrated in table 4.

TABLE 5.

ITEM STATISTICS OF PROBLEM-SOLVING STRATEGIES (PROB)

\begin{tabular}{|c|c|c|c|}
\hline Items & $\mathbf{N}$ & M & SD \\
\hline I adjust my reading speed according to what I am reading. & 110 & 4.32 & 1.06 \\
\hline When text becomes difficult, I pay closer attention to what I am reading. & 110 & 3.89 & 0.99 \\
\hline When text becomes difficult, I reread to increase my understanding. & 110 & 3.78 & 1.01 \\
\hline I think about whether the content of the text fits my reading purpose. & 110 & 3.51 & 0.89 \\
\hline I stop from time to time and think about what I am reading. & 110 & 3.42 & 0.93 \\
\hline I read slowly but carefully to be sure I understand what I am reading. & 110 & 3.1 & 1.08 \\
\hline I try to picture or visualize information to help remember what I read. & 110 & 2.8 & 0.91 \\
\hline I guess the meaning of unknown words by separating different parts of a word. & 110 & 2.67 & 0.97 \\
\hline I try to get back on track when I lose concentration. & 110 & 2.01 & 1.1 \\
\hline Total & & 3.32 & \\
\hline
\end{tabular}

Problem solving strategies are tabulated in table 5 and as it indicates students most often adjust their reading speed to what they are reading. When the text gets difficult they pay closer attention to what I am reading and reread to increase my understanding. Advanced Iranian language learners think about whether the content of the text fits their reading purpose or not. As the least used strategy they get back on track when they lost concentration.

\section{DisCUSSION AND CONCLUSION}

Since advanced students have already had this chance to get exposed to various texts they must be talented good readers to accomplish requirements in academic studies. Based on the findings, there is a reasonable awareness of all the reading strategies. In fact, all the skills are approximately of the same importance to the readers.

As the most striking strategy, when text becomes difficult, readers pay closer attention to what I am reading. Besides, the participants reread to increase their understanding.as an alternative when the text becomes more complicated. 
Ozek and Civelek (2006) conducted a study on identifying the reading strategies that are mostly used by ELT students between the 1st and 4th year students in Turkey. They findings suggest that each stage of reading namely prereading, while-reading, and post-reading stages was dealt with using different reading strategies. Unlike the present study, they found out that substantial differences exist on the use of cognitive reading strategies in case of students' gender, age, and proficiency in reading, school source, and duration in learning English.

Four-year technical college students were the main participants in the study Hsu (2007) conducted in Taiwan in order to investigate the use of English reading strategies. Metacognitive strategy was the most often used reading strategy based on his findings followed by social/affective strategy category. There was a tendency toward taking advantage of some specific kinds of strategies comparing the two groups of effective and ineffective language learners. While both groups generally use problem solving strategies, they do not choose to use support reading strategies. Although the two groups pay closer attention to what they are reading and underline and circle information in the text, they do not prefer to skim the text first. In terms of gender, there was a tendency to use cognitive strategies and social/affective strategies in females but no significant difference between males and females in general use of strategies.

Unlike the findings of the present study Amer et al. (2010) found that participants tend to underline or circle information in the text to help them remember the information. Furthermore, they pay closer attention to what they are reading and reread the text, when text becomes problematic.

On the other hand, $\mathrm{Li}$ (2010) found that in each individual category as well combined sub-categories female readers show higher use of reading strategies than males. Furthermore, female participants are more careful and considerate.

Support Reading Strategies and Problem solving strategies were mostly picked by Iranian advanced EFL learners and global reading strategies were almost neglected by them. In terms of the two groups of males and females although there was not a significant difference in strategy choice, females had more tendency toward support reading strategies than the male group.

Li (2010) conducted a study with senior middle school students in China in order to investigate their awareness of reading strategy. Unlike the findings of the current study, he found that students preferred Problem Solving Reading Strategies rather than Global and Support Reading Strategies and they were moderately aware of all the strategies.

Amer et al. (2010) did a research on the online reading strategies of Omani EFL university first-year students and senior student teachers. The findings illustrated a statistically significant difference between fourth-year students and first-year students only in global reading strategies. High-proficient readers have a tendency to use global strategies than readers with low proficiency. First-year students also picked more support strategies than senior students.

Sarıçoban (2002) investigated the strategy choice of effective readers in pre-reading, reading and post-reading stages of instruction in classroom language learning. Global reading strategies were the first preference of successful EFL learners.

The already mentioned reading strategies can be implemented in education context as well as any other extensive or intensive reading activity. The participants of the current study were groups in very good and good readers therefore the results and strategy choices can be picked up by any other language readers. Although identifying the strategy type for each stage of reading can be the purpose of other studies, there should be a desire to design reading activities in a way to make it possible for the students pick up any of these strategies which can make their language learning atmosphere more meaningful.

\section{REFERENCES}

[1] Allan, J., \& Bruton, A. (1997). Squeezing-Out the Juice: Perceptions of Reading in the Secondary School. SCRE Spotlights.

[2] Amer,A. Al Barwani, T. Mahmoud Ibrahim, M. (2010). Student teachers' perceived use of online reading strategies. International Journal of Education and Development using Information and Communication Technology. (IJEDICT). 6(4). 102-113.

[3] Anderson, N. (1999). Exploring second language reading: Issues and strategies. Boston:Heinle.

[4] Carrell, P. (1989). Metacognitive awareness and second language reading. The Modern Language Journal. 73(2), 121-134

[5] Garner, R. (1987). Metacognition and reading comprehension. Norwood. NJ: Ablex publishing.

[6] Goodman, K.S. (1995). The reading process. New York: Cambridge University Press.

[7] Grabe, W. (1991). Current developments in second language reading research. TESOL Quarterly, 25/3, 375-406.

[8] Greenwood, J. (1998). Class readers. HongKong: Oxford University Press.

[9] Grellet, F. (1996). Developing reading skills: A practical guide to reading comprehension exercises. Cambridge: Cambridge University Press.

[10] Hsu, S. C. (2007). Reading Strategies Used by EFL Technical Students. English Teaching e-Monthly, 22(1). 155-179.

[11] Jeon, E. H. (2011). Contribution of Morphological Awareness to Second - Language Reading Comprehension. The Modern Language Journal, 95(2), 217-235.

[12] Karbalaei A. (2010). A Comparison of the Metacognitive Reading Strategies Used by EFL and ESL Readers. The Reading Matrix, 10(2), 165-180.

[13] Krashen, S. (1985). Insights and inquirie. Hayward, CA: Alemany Press.

[14] Li, F. (2010). A Study of English Reading Strategies Used by Senior Middle School Students. Asian Social Science. 6(10). 184200.

[15] Mikulecky, B. S. (2008). Teaching reading in a second language. Retrieved on April 2017, from: http://longmanhomeusa. com. 
[16] Mokhtari, K. \& Reichard, C. (2002). Assessing students metacognitive awareness of reading strategies. Journal of Educational Psychology, 94(2), 249-259.

[17] Nuttall, C. (1996). Teaching Reading Skills in a foreign language. Oxford: Heinemann.

[18] Ozek, Y.\& Civelek, M. (2006). A Study on the Use of Cognitive Reading Strategies by ELT Students. The Asian EFL Journal, 14 1-26.

[19] Pang, S., Muaka, A., Bernhardt, B., \& Kamil, M. L. (2003). Teaching reading. Belgium: International Academy of Education.

[20] Park, H. R., \& Kim, D. (2011). Reading-strategy use by English as a second language learners in online reading tasks. Computers \& Education, 57(3), 2156-2166.

[21] Peregoy, S. F. \& Boyle, O. F. (2001). Reading, writing, \& learning ESL. New York: Longman.

[22] Ransom, G.A. (1978). Preparing to Teach Reading. Boston: Little Brown Company.

[23] Saricoban A. (2002). Reading strategies of successful readers through the three phase approach. The Reading Matrix 23(4) ,116.

[24] Takallou, F. (2011). The Effect of Metacognitive Strategy Instruction on EFL Learners' Reading Comprehension Performance and Metacognitive Awareness. Asian EFL Journal, 13(1). 26-34.

[25] Tercanlioglu, L. (2004). Postgraduate students' use of reading strategies in L1 and ESL contexts: Link to success. International Education Journal, 5/4. 89-110.

[26] Urquhart, S. and Weir, C. (1998). Reading in a second language: Process, product and practice. London: Longman.

[27] Williams, E. (1996). Reading in the language classroom. Malaysia: Modern English Publications.

Mehdi Hatami is a PhD student of Teaching English as a Foreign Language at the department of English Language at Islamic Azad University, Ahar, Iran. He is a full time English teacher and his fields of interests are reading and language testing.

Hanieh Davatgari Asl is an assistant professor of Teaching English as a Foreign Language at the department of English Language at Islamic Azad University, Ahar, Iran. 